\title{
Hereditary Nonspherocytic Hemolytic \\ Disease Associated with an Altered Phospholipid \\ Composition of the Erythrocytes
}

\author{
Ernst R. Jaffé and Eugene L. Gottrried \\ From the Department of Medicine and the Human Heredity Center, Albert \\ Einstein College of Medicine-Bronx Municipal Hospital Center, \\ Bronx, New York 10461
}

A в S T R A C T A hemolytic disorder with mild hyperbilirubinemia and reticulocytosis of 6 to $15 \%$ was documented in eight members of a large family from the Dominican Republic and was presumed to be present in eight other members. The disorder appeared to be inherited as an autosomal dominant characteristic.

Analysis of phospholipids by quantitative thinlayer chromatography revealed a distinct increase in phosphatidyl choline (lecithin) to $35.5 \pm \mathrm{sD}$ $1.3 \%$ of the total (normal : $28.2 \pm 1.4 \%$ ) in erythrocytes of affected members of the family, but not in the cells of unaffected relatives. The alteration appeared to constitute an absolute increase in lecithin content, rather than a decrease in other phospholipids. Erythrocytes from patients with other varieties of hereditary hemolytic disorders and comparable levels of reticulocytosis had normal phospholipid compositions. Plasma lipids of six affected members of the family were not unusual with respect to total lipid weight, total phospholipid, and cholesterol. Three patients with liver disease and jaundice were found to have marked increases in the lecithin content of the erythrocytes. but they also had extremely high plasma levels of total lipid, phospholipids, and cholesterol.

Osmotic fragility of the erythrocytes of affected patients was decreased and the increase in fragility

This paper was presented in part at the 58th Annual Meeting of the American Society for Clinical Investigation, Atlantic City, N. J., 1 May 1966.

Received for publication 20 December 1967 and in reinsed form 5 February 1968. after incubation for $24 \mathrm{hr}$ was less than that observed with normal erythrocytes. Autohemolysis after $48 \mathrm{hr}$ was slightly increased and was corrected to nearly normal by the addition of glucose. The activities of 15 enzymes of the erythrocytes of the propositus were normal or elevated and the adenosine triphosphate content was normal. An abnormal hemoglobin could not be demonstrated. The life span of isologous erythrocytes in the propositus was reduced, but homologous erythrocytes survived normally.

A causal relationship between the altered phospholipid composition and the hemolytic disorder has not been established.

\section{INTRODUCTION}

Hereditary hemolytic disorders are known to be associated with alterations in the metabolism and shape of erythrocytes, with decreased activities of certain enzymes and with abnormalities in the structure and synthesis of hemoglobin. Consistent, confirmed changes in the lipids of erythrocytes in disorders which are primarily hemolytic have not been reported. The content of phosphatidyl choline (lecithin) is decreased in the erythrocytes of patients with abetalipoproteinemia (acanthocytosis) in which mild or intermittent hemolysis may occur $(1,2)$. This alteration in phospholipid composition, however, is considered to be secondary to changes in the plasma phospholipids (3). The increased susceptibility of acanthocytes to hemolysis in vitro and, perhaps, in vivo, has been attributed to lipid peroxidation as a consequence of 
a severe deficiency in vitamin $\mathrm{E}(4,5)$. A decreased content of lecithin also has been observed in the erythrocytes and plasma of a Japanese child with hemolysis, dwarfism, and mental retardation, but without a family history of hemolytic anemia (6). The present report describes a nonspherocytic hemolytic disorder in a large family from the Dominican Republic. This abnormality appears to be inherited as an autosomal dominant characteristic and is associated with an increase in the lecithin content of the erythrocytes.

\section{METHODS}

Lipids of erythrocytes and plasma. Freshly drawn venous blood, anticoagulated with disodium ethylenediaminetetraacetate (EDTA) $(1 \mathrm{mg} / \mathrm{ml}$ of blood), was centrifuged at $250 \mathrm{~g}$ for $10 \mathrm{~min}$ to separate erythrocytes from plasma. The erythrocytes were washed three times in $0.154 \mathrm{~m}$ sodium chloride solution with centrifugation and then were resuspended in an approximately equal volume of a phosphate-buffered isotonic sodium chloride solution $(\mathrm{pH} 7.4)$ for counting with a Coulter model $\mathrm{F}$ electronic particle counter and for determination of packed cell volume. The plasma was centrifuged again at $3000 \mathrm{~g}$ for $10 \mathrm{~min}$ in order to remove remaining leukocytes and platelets.

Lipids were extracted from the plasma and erythrocyte samples immediately after the final washing. Redistilled reagent grade methanol and chloroform were deaerated with nitrogen and cooled to $2-5^{\circ} \mathrm{C}$ just before use. 1 volume of sample was added to 7 volumes of methanol and the mixture was stirred constantly by means of a magnetic stirrer for $15 \mathrm{~min} ; 14$ volumes of chloroform were then added and stirring was continued for 1 hr at $4^{\circ} \mathrm{C}$. The mixture was filtered through solventwashed filter paper, and the residue was subjected to a second extraction with 10 volumes of chloroform-methanol $2: 1(\mathrm{v} / \mathrm{v})$. No significant increase in yield of lipid phosphorus was achieved by prolonging extraction time beyond $1 \mathrm{hr}$ or by increasing the temperature of the solvents to room temperature or higher. The chloroform-methanol extracts were washed by the method of Folch, Lees, and Sloane Stanley (7) with $0.1 \mathrm{M}$ potassium chloride solution in the upper phase. The lower phase was taken to dryness in a rotary evaporator at $37^{\circ} \mathrm{C}$, and the lipid was redissolved immediately in cold chloroform-methanol $2: 1$ $(\mathrm{v} / \mathrm{v})$. Washed lipid extracts were filtered again and were stored at $-20^{\circ} \mathrm{C}$ in tightly stoppered amber bottles. Total lipid weight and lipid phosphorus were determined as previously described (8). Cholesterol was measured by the method of Leffler (9) and plasmalogen content was estimated by the iodination method of Gottfried and Rapport (10) with the $+8 \%$ correction factor recommended by Rapport and Norton (11). Individual phospholipids were separated and measured by quantitative thin-layer chromatography on "basic" Silica Gel $\mathrm{H}^{1}$ with

${ }^{1}$ E. Merck, Darmstadt, Germany. chloroform-methanol-acetic acid-water $25: 15: 4: 2(\mathrm{v} / \mathrm{v})$ $(8,12)$.

Fragility of crythrocytcs. Osmotic fragility was determined before and after incubation of sterile, defibrinated blood for $24 \mathrm{hr}$ at $37^{\circ} \mathrm{C}$ (13). Autohemolysis was measured as described by Selwyn and Dacie (14), but with heparin as anticoagulant (15). Mechanical fragility was estimated before and after incubation at $37^{\circ} \mathrm{C}$ for 24 $\mathrm{hr}$ (13). Spontaneous hemolysis of clotted blood and of blood anticoagulated with disodium EDTA was determined after storage at $5^{\circ} \mathrm{C}$ for 24 and $48 \mathrm{hr}$ (16).

Examinations for abnormal hemoglobins. Standard methods were employed for hemoglobin electrophoresis on starch gel at $\mathrm{pH} 8.6$ (17) and on agar gel at $\mathrm{pH} 8.6$ and 7.5 (18). Electrophoresis was also performed at $\mathrm{pH}$ 8.6 with borate and Tris-citrate-borate buffers with and without added para-hydroxy mercuribenzoate (19). The method of Dacie et al. (20) was used to rule out the presence of a heat-unstable hemoglobin. Inclusion bodies characteristic of hemoglobin $\mathrm{H}$ were not seen after incubation of blood with new methylene blue for $4 \mathrm{hr}$ at room temperature (21). The presence of Heinz bodies was evaluated after incubation of sterile blood for $48 \mathrm{hr}$ at $37^{\circ} \mathrm{C}$ with and without added glucose (22). Alkali-resistant hemoglobin (fetal) was measured by the method of Singer, Chernoff, and Singer (23).

Activities of enzymes, concentrations of cofactors, and metabolism of erythrocytes. The activities of glucose-6phosphate dehydrogenase (24), pyruvate kinase (25), and oxidized glutathione reductase (22) were assayed in erythrocytes from most members of the family who were studied. The activities of the following enzymes in the propositus' erythrocytes were kindly determined by $\mathrm{Dr}$. Arthur S. Schneider, Los Angeles, Calif.: hexokinase, phosphoglucose isomerase, phosphofructokinase, aldolase, glyceraldehyde-3-phosphate dehydrogenase, triosephosphate isomerase, phosphoglycerate kinase, phosphoglyceric mutase, enolase, pyruvate kinase, lactate dehydrogenase, glucose-6-phosphate dehydrogenase, 6-phosphogluconic dehydrogenase, and oxidized glutathione reductase (26). Glutathione peroxidase activity was determined in the laboratory of Dr. Ruth T. Gross (22).

The concentrations of reduced glutathione (GSH) and its stability upon incubation with acetylphenylhydrazine were determined as described by Beutler (27); 5,5'dithio-bis-(2-nitrobenzoic acid) was used for the measurement of GSH (28). The concentrations of adenosine triphosphate (ATP) and adenosine diphosphate (ADP) were measured by Mr. Joseph Fuhr (25). Utilization of glucose and production of lactate and pyruvate from glucose and inosine were determined as described elsewhere (29).

Other examinations. Routine hematological and chemical determinations were performed by standard methods in the laboratories of the Bronx Municipal Hospital Center.

\section{RESULTS}

Clinical data and case report. The illness of the propositus (III-5) first became clinically ap- 
parent at about age 10 when he suffered a severe hemolytic episode in Moca, Dominican Republic. A diagnosis of Lederer's anemia was made and he received whole blood transfusions. A 16 year old sister (III-3) had a similar hemolytic episode at about the same time. He had no known intercurrent illness or exposure to drugs or chemicals. After several months of convalescence, he recovered. He experienced no further episodes of overt, acute hemolysis and completed his education to become an instructor in agricultural techniques. Although he participated in all normal activities, he was noted to have a decreased exercise tolerance, pallor, and a yellowish skin color. At age 21 , there was a decrease in exercise tolerance. Examination revealed total serum bilirubin, $4 \mathrm{mg} /$ $100 \mathrm{ml}, 35 \%$ packed erythrocyte volume, hemoglobin, $13.6 \mathrm{~g} / 100 \mathrm{ml}, 13 \%$ reticulocytes, urine urobilinogen present in a dilution of $1: 80$, negative Coombs' test, and erythroid hyperplasia of the bone marrow. Subsequently, he noted occasional episodes of right upper quadrant pain, nausea, and vomiting. After one such episode, he was told that he had hepatitis. He was first examined at the Bronx Municipal Hospital Center (No. 371640) at age 23 in February, 1965, because of decreased exercise tolerance and some decrease in appetite with an 18-20 $\mathrm{lb}$ weight loss in the preceding 3 months.
Physical examination revealed a thin young man with a sallow, slightly icteric complexion. A single spider angioma was present over the right sternoclavicular joint. The liver was enlarged $3-4 \mathrm{~cm}$ below the right costal margin, the spleen was palpable $2-3 \mathrm{~cm}$ below the left costal margin, and both organs were slightly tender. Results of funduscopic and neurologic examinations were within normal limits. There was no evidence of chronic ulcerations on the legs.

Pertinent diagnostic hematologic data are summarized in Table I. A partially compensated hemolytic anemia was present with a reticulocytosis that varied between 6 and $15 \%$. Stained smears of peripheral blood revealed nonspecific variations in the morphology of the erythrocytes which were consistent with a hemolytic process. These changes included moderate anisocytosis, mild poikilocytosis with occasional target cells, some polychromatophilia, rare basophilic stippling, and very rare spherocytes (Fig. 1). The erythrocytes appeared to be well filled with hemoglobin. The total leukocyte and platelet counts were normal and the distribution and morphology of the leukocytes were not unusual. Tests of liver function, including transaminases, were normal, except for a $2+$ to $3+$ cephalin flocculation. The unconjugated serum bilirubin concentration varied between 2 and $4 \mathrm{mg} / 100 \mathrm{ml}$, while the direct-reacting fraction

TABLE I

Diagnostic Hematologic Data

\begin{tabular}{|c|c|c|c|c|c|c|c|c|c|c|c|c|}
\hline \multirow[t]{2}{*}{ Subjects } & \multirow{2}{*}{$\frac{\text { Age }}{y r}$} & \multirow{2}{*}{$\begin{array}{c}\mathrm{Hb} \\
g / 100 \\
m l\end{array}$} & \multirow{2}{*}{$\begin{array}{c}\begin{array}{c}\text { Packed } \\
\text { cell } \\
\text { volume }\end{array} \\
\%\end{array}$} & \multirow{2}{*}{$\begin{array}{c}\begin{array}{c}\text { Red } \\
\text { cell } \\
\text { count }\end{array} \\
\begin{array}{c}10^{6} / \\
\mathrm{mm}^{3}\end{array}\end{array}$} & \multirow{2}{*}{$\begin{array}{c}\begin{array}{c}\text { Reticu- } \\
\text { locytes }\end{array} \\
\%\end{array}$} & \multirow[t]{2}{*}{$\begin{array}{c}\text { Decreased } \\
\text { osmotic } \\
\text { fragility }\end{array}$} & \multicolumn{2}{|c|}{$\frac{\text { Autohemolysis }}{\text { Control* Glucose* }^{*}}$} & \multicolumn{2}{|c|}{$\frac{\text { Serum bilirubin }}{\text { Total Conjugated }}$} & \multirow{3}{*}{$\begin{array}{c}\begin{array}{c}\text { Hapto- } \\
\text { globin } \ddagger\end{array} \\
\begin{array}{c}m g / 100 \\
m l\end{array}\end{array}$} & \multirow{2}{*}{$\frac{\begin{array}{c}\text { Alkali } \\
\text { resistant } \\
\text { Hb\& }\end{array}}{\%}$} \\
\hline & & & & & & & $\%$ & $\%$ & $\begin{array}{c}m g / 100 \\
m l\end{array}$ & $\begin{array}{c}m g / 100 \\
m l\end{array}$ & & \\
\hline \multicolumn{12}{|l|}{ Affected } & \\
\hline III-5 & 23 & 12.6 & 37.0 & 4.00 & 12.9 & Yes & 5.1 & 1.4 & 2.5 & 0.4 & $<50$ & 2.0 \\
\hline III-3 & 32 & 13.0 & 39.0 & 4.23 & 6.8 & & & & 2.4 & 0.5 & 18 & 7.0 \\
\hline III-25 & 26 & 15.9 & 43.5 & 5.00 & 8.8 & Yes & 2.7 & 0.6 & 3.6 & 0.7 & 26 & 3.5 \\
\hline III-26 & 22 & 11.4 & 33.0 & & 14.7 & Yes & 2.2 & 1.0 & 3.4 & 0.3 & 35 & 4.7 \\
\hline II-2 & 63 & 13.0 & 37.0 & & 9.2 & & & & 2.8 & 0.7 & $<50$ & 5.0 \\
\hline II-3 & 62 & 12.1 & 35.0 & & 9.6 & & & & 5.2 & 1.1 & $<50$ & 2.3 \\
\hline II-6 & 54 & 13.1 & 37.5 & & 13.6 & Yes & 7.7 & 1.2 & 2.4 & 0.3 & 42 & 2.6 \\
\hline II-9 & 45 & 10.8 & 32.5 & 3.10 & 10.0 & & & & & & & \\
\hline \multicolumn{13}{|c|}{ Unaffected } \\
\hline III-1 & 37 & 13.2 & 39.0 & & 0.8 & & & & 0.6 & 0.3 & $>\mathbf{5 0}$ & 1.5 \\
\hline III-2 & 34 & 13.6 & 40.0 & & 1.4 & & & & 0.4 & 0.2 & $>50$ & 1.3 \\
\hline III-4 & 29 & 13.8 & 42.0 & & 1.2 & No & 1.8 & 0.1 & 1.0 & 0.5 & 94 & 0.1 \\
\hline III-24 & 29 & 13.6 & 42.0 & & 2.0 & No & & & 0.2 & 0.1 & 100 & \\
\hline II-1 & 62 & 14.9 & 42.0 & & 1.3 & & & & 1.0 & 0.3 & $>50$ & 1.1 \\
\hline
\end{tabular}

* Normal control less than $2.0 \%$ hemolysis, with glucose less than $0.5 \%$ hemolysis.

$\ddagger$ Normal greater than $50 \mathrm{mg} / 100 \mathrm{ml}$.

$\$$ Normal less than $2.5 \%$. 


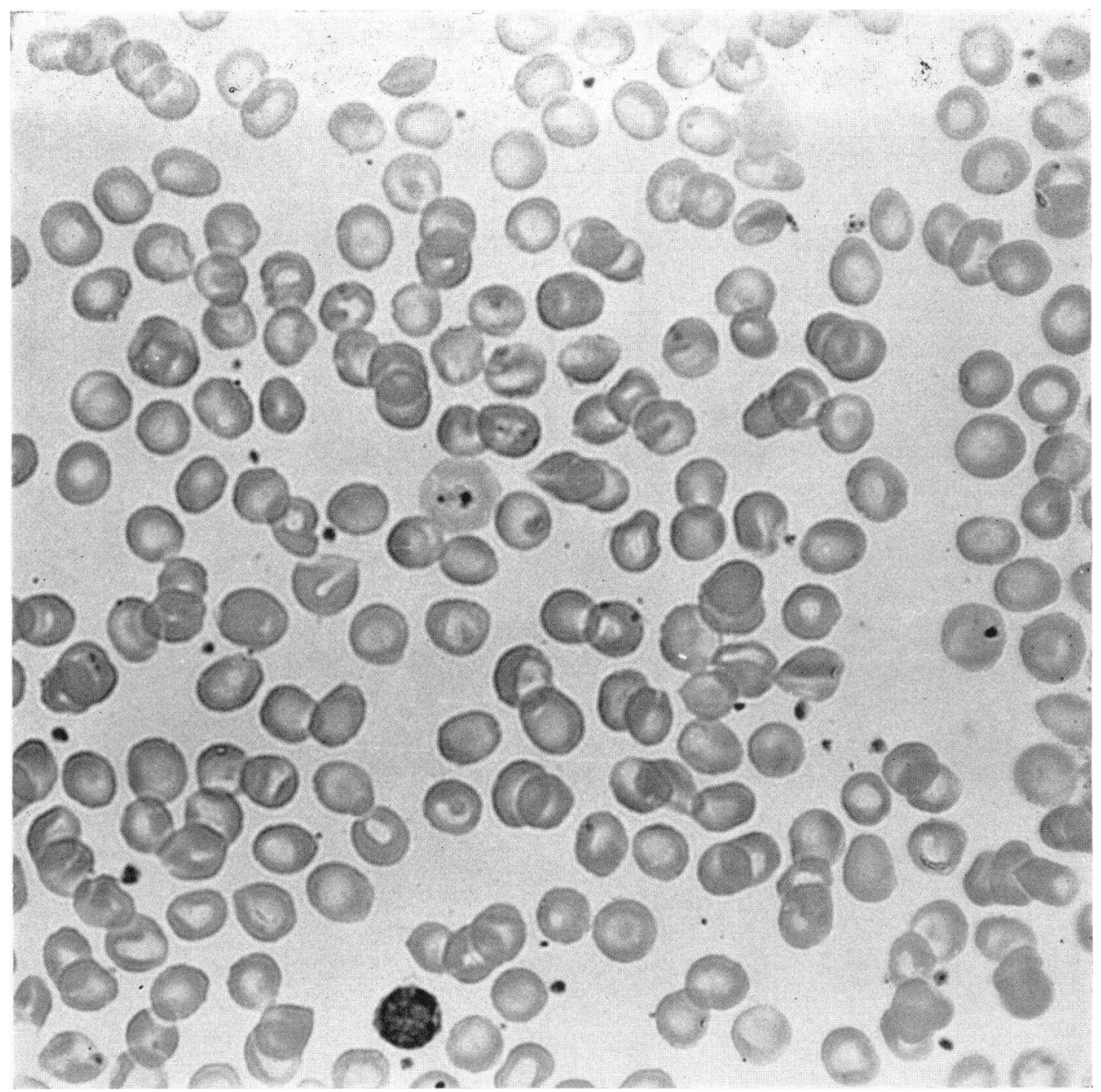

FIGURE 1 Photomicrograph of smear of peripheral blood of propositus. Wright's stained smear. $\times 430$.

was normal. Oral cholecystography demonstrated a normally functioning gallbladder without evidence of stones. X-rays of the skull revealed widened diploic spaces and separated tables. Marked normoblastic erythroid hyperplasia was noted in a smear of aspirated bone marrow. Needle biopsy of the liver demonstrated diffuse hemosiderin deposits in the cytoplasm of parenchymal cells, but no acute or chronic inflammatory response. The serum iron concentration was 250 $\mu \mathrm{g} / 100 \mathrm{ml}$ and the total iron-binding capacity was $288 \mu \mathrm{g} / 100 \mathrm{ml}, 87 \%$ saturated. Coombs' test and examinations for cold and warm agglutinins and for acid hemolysins were negative. The urine was of normal color, hemosiderin was not observed and urobilinogen was present in a dilution of $1: 80$ $1: 160$. The concentrations of porphobilinogen and of delta amino-levulinic acid in the urine were normal.

The osmotic fragility of the patient's erythrocytes was decreased (Fig. 2). After incubation for $24 \mathrm{hr}$, the increase in fragility was less than that observed with blood from normal subjects and much less than that noted with blood from the patient with hereditary spherocytosis (Fig. 3). There was, however, a small population of cells which did become more fragile. Autohemolysis after incubation for $48 \mathrm{hr}$ was moderately increased to $5.1 \%$ and was reduced to nearly normal levels by the addition of glucose, inosine, or ATP. Mechanical fragility before and after incubation at $37^{\circ} \mathrm{C}$ and spontaneous hemolysis of clotted and anticoagulated blood stored at $5^{\circ} \mathrm{C}$ were normal. An abnormal hemoglobin could not be demon- 
strated by electrophoresis in several different systems. The concentration of hemoglobin $\mathrm{A}_{2}$ was normal. Heinz bodies were not seen, even after prolonged incubation. Hemoglobin $\mathrm{H}$ bodies were not observed and there was no heat-unstable hemoglobin. Alkali resistant (fetal) hemoglobin represented $2 \%$ of the total hemoglobin.

The concentration of ATP in the erythrocytes was $5.26 \mu$ moles/g of hemoglobin (normal : 2.334.76) and the ADP content was $0.46 \mu$ moles $/ g$ of hemoglobin (normal : $0.18-0.57$ ). The concentration of GSH was $69 \mathrm{mg} / 100 \mathrm{ml}$ of erythrocytes (normal : 60-90) and decreased by 10\% (normal: 0-20) after incubation for $2 \mathrm{hr}$ with acetylphenylhydrazine. Increased glucose utilization and increased lactate and pyruvate production were observed with erythrocytes from the propositus, as well as with erythrocytes from four affected relatives. The results, however, were indistinguishable from values obtained with erythrocytes from patients with comparable levels of reticulocytosis associated with other diseases (hemoglobinopathies,

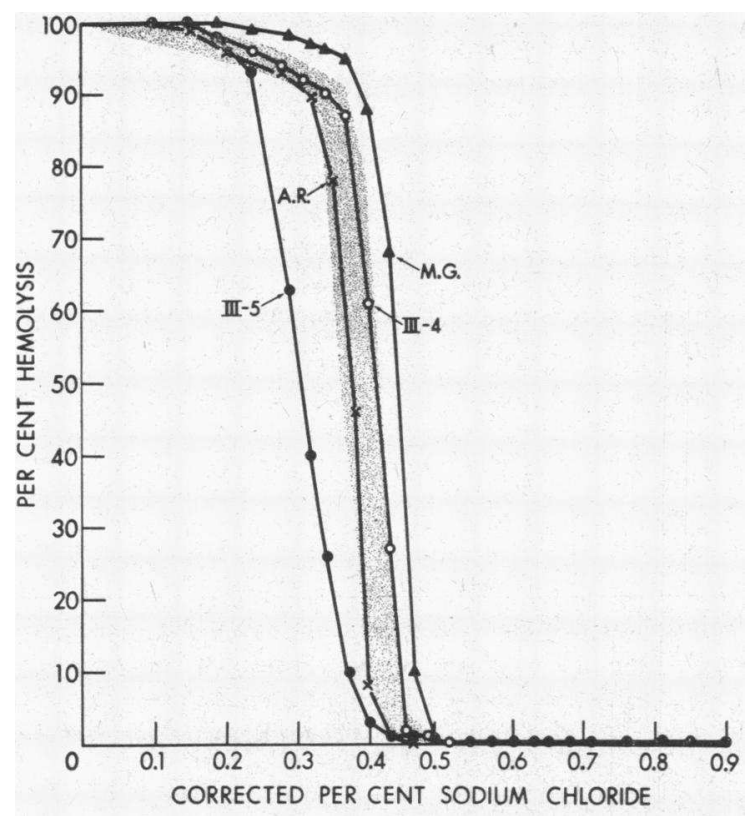

FIGURE 2 Osmotic fragility before incubation. III-5, propositus, $11 \%$ reticulocytes ; III-4, brother of propositus, $1 \%$ reticulocytes. A. R., patient with congenital nonspherocytic hemolytic disease associated with severe deficiency in the activity of glucose-6-phosphate dehydrogenase, $25 \%$ reticulocytes. M. G., patient with untreated hereditary spherocytosis, $5 \%$ reticulocytes. Shaded area, normal range.

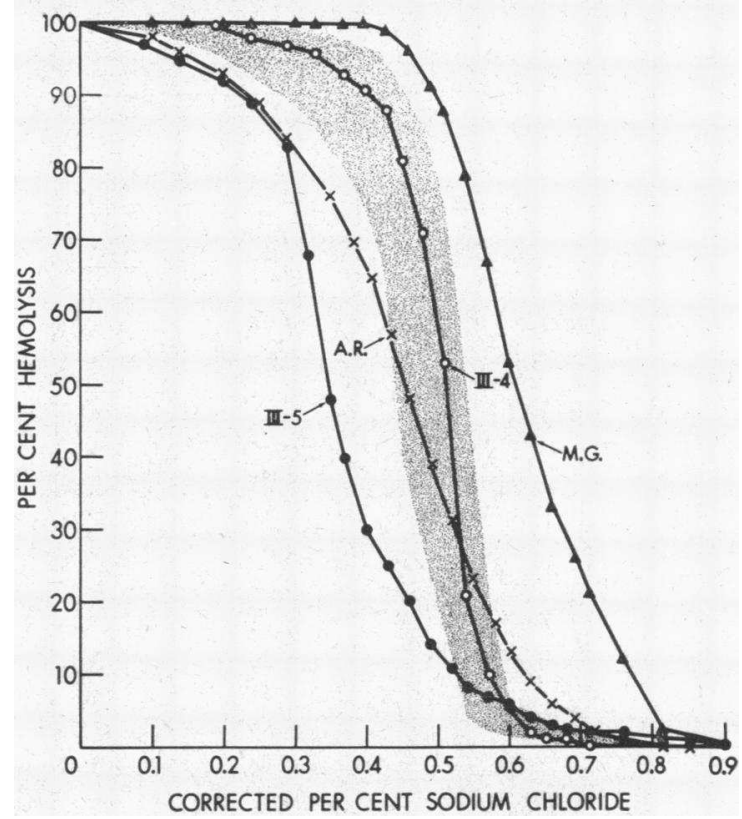

Figure 3 Osmotic fragility after incubation. Defibrinated, sterile blood was incubated for $24 \mathrm{hr}$ at $37^{\circ} \mathrm{C}$. III-5, propositus, $11 \%$ reticulocytes, III-4, brother of propositus, $1 \%$ reticulocytes. A. R., patient with congenital nonspherocytic hemolytic disease associated with severe deficiency in the activity of glucose-6-phosphate dehydrogenase, $25 \%$ reticulocytes. M. G., patient with untreated hereditary spherocytosis, $5 \%$ reticulocytes. Shaded area, normal range.

megaloblastic anemia responding to therapy, and unexplained hemolytic disorders). Normal values were obtained with erythrocytes from two unaffected family members. The levels of activity of 15 enzymes in the erythrocytes of the propositus were either normal or elevated, in keeping with the reticulocytosis.

The half-time of disappearance $\left(t_{\frac{1}{2}}\right)$ of the propositus' own ${ }^{51}$ chromium-labeled erythrocytes was reduced to 10.6 days (normal: $28 \pm 3$ days). Organ scanning revealed a splenic localization index of 1.1 (30). Compatible blood from a normal donor, labeled with ${ }^{51}$ chromium, had a $t_{1}$ of 28 days. Surface counting indicated progressive accumulation of radioactivity in the spleen, comparable to the sequestration noted with isologous-labeled erythrocytes. These findings were compatible with some degree of hypersplenism superimposed upon an intrinsic erythrocyte abnormality, but excluded the possibility of primary hypersplenism. The studies of survival of erythrocytes in vivo also 
TABLE II

\begin{tabular}{|c|c|c|c|c|c|c|}
\hline \multirow[t]{2}{*}{ Subjects } & \multicolumn{2}{|c|}{ Total lipid weight } & \multicolumn{2}{|c|}{ Cholesterol } & \multicolumn{2}{|c|}{ Lipid phosphorus } \\
\hline & $\begin{array}{c}g \times 10^{-13} / \\
\text { cell }\end{array}$ & $\begin{array}{c}m g / m l \\
\text { packed } R B C\end{array}$ & $\begin{array}{c}\text { moles } \times 10^{-16} / \\
\text { cell }\end{array}$ & $\begin{array}{c}\text { moles } \times 10^{-6} / \\
\text { ml packed } \\
R B C\end{array}$ & $\begin{array}{c}\text { g-atoms } \\
\times 10^{-16} / \\
\text { cell }\end{array}$ & $\begin{array}{c}\text { g-atoms } \\
\times 10^{-6} / \mathrm{ml} \\
\text { packed } R B C\end{array}$ \\
\hline Normal subjects & 4.98 & 5.67 & 3.44 & 3.91 & 3.64 & 4.14 \\
\hline$(n=10) \pm S D(31)$ & \pm 0.58 & \pm 0.52 & \pm 0.40 & \pm 0.41 & \pm 0.31 & \pm 0.26 \\
\hline \multicolumn{7}{|l|}{ C. family, affected } \\
\hline III-5 & 6.35 & 6.32 & 3.51 & 3.49 & 4.55 & 4.53 \\
\hline III-3 & 5.95 & 5.98 & 4.59 & 4.61 & 3.84 & 3.86 \\
\hline III-25 & 5.21 & 5.59 & 3.05 & 3.27 & 3.97 & 4.26 \\
\hline III-26 & 5.00 & 5.35 & 3.22 & 3.45 & 4.23 & 4.53 \\
\hline II-2 & 5.68 & 5.55 & 3.71 & 3.63 & 4.45 & 4.35 \\
\hline II -3 & 6.11 & 5.73 & 3.28 & 3.08 & 4.36 & 4.09 \\
\hline II-6 & 5.29 & 5.47 & 3.98 & 4.12 & 3.96 & 4.09 \\
\hline II-9 & 5.91 & 5.85 & 3.10 & 3.07 & 3.97 & 3.93 \\
\hline Mean values & $5.69 *$ & 5.73 & 3.56 & 3.59 & $4.17 \ddagger$ & 4.20 \\
\hline$\pm \mathrm{SD}(31)$ & \pm 0.48 & \pm 0.31 & \pm 0.52 & \pm 0.53 & \pm 0.26 & \pm 0.26 \\
\hline \multicolumn{7}{|l|}{ C. family, unaffected } \\
\hline III-1 & 5.63 & 5.97 & 4.21 & 4.46 & 3.81 & 4.04 \\
\hline III-2 & - & - & - & - & 3.23 & 3.62 \\
\hline III-4 & 5.07 & 5.83 & 2.77 & 2.90 & 3.45 & 3.61 \\
\hline III-24 & 5.01 & 5.22 & 3.80 & 3.96 & 4.00 & 4.17 \\
\hline II-1 & 5.45 & 6.10 & 3.76 & 4,21 & 3.52 & 3.94 \\
\hline Mean values & 5.29 & 5.78 & 3.63 & 3.88 & 3.60 & 3.88 \\
\hline$\pm \mathrm{SD}(31)$ & \pm 0.30 & \pm 0.39 & \pm 0.61 & \pm 0.69 & \pm 0.30 & \pm 0.25 \\
\hline \multicolumn{7}{|l|}{ Hemolytic disorders } \\
\hline M.O. (HS) & 4.61 & 5.73 & 3.04 & 3.78 & 3.00 & 3.73 \\
\hline M.G. (HS) & 3.84 & 4.92 & 2.76 & 3.54 & 3.06 & 3.92 \\
\hline N.L. (G6PD-) & 3.94 & 4.70 & 2.89 & 3.45 & 3.32 & 3.96 \\
\hline A.R. (G6PD-, NSHD) & 6.58 & 5.31 & 4.13 & 3.33 & 4.86 & 3.92 \\
\hline R.M. (Hb Gun Hill $_{\text {) }}$ & 5.37 & 5.18 & 3.73 & 3.60 & 3.90 & 3.76 \\
\hline E.McC. (NSHD) & 5.21 & 5.43 & 3.62 & 3.77 & 3.48 & 3.63 \\
\hline G.F. (NSHD) & 3.86 & 5.29 & 2.66 & 3.64 & 2.90 & 3.97 \\
\hline \multicolumn{7}{|l|}{ Liver disease } \\
\hline J.E. & 6.68 & 7.49 & 4.58 & 5.14 & 4.32 & 4.84 \\
\hline M.S. & 6.62 & 6.00 & 5.42 & 4.91 & 3.60 & 3.26 \\
\hline D.L. & 5.90 & 5.40 & 5.84 & 5.35 & 3.77 & 3.45 \\
\hline
\end{tabular}

Abbreviations: HS, hereditary spherocytosis; G6PD-, glucose-6-phosphate dehydrogenase deficiency; NSHD, nonspherocytic hemolytic disease, etiology undetermined; PC, phosphatidyl choline; PS, phosphatidyl serine; PI, phosphatidyl inositol; PE, ethanolamine phosphoglycerides; SPH, sphingomyelin ; LL, lysolecithin (includes other substances migrating near origin in thin-layer chromatograms); and PA, phosphatidic acid (includes other substances migrating near solvent front in thin-layer chromatograms).

$* P<0.02$.

$\ddagger P<0.005$.

$\S P<0.001$.

demonstrated that the defect was not acquired by Unit Kindred No. 193) is presented in Fig. 4. normal donor cells during at least 14 days of The ancestors of this family had lived in the observation.

Family history and studies of family members. The pedigree of the large C. family (Heredity Dominican Republic for many years, having come originally from Spain. Pertinent laboratory data are summarized in Table I. On the basis of labora- 


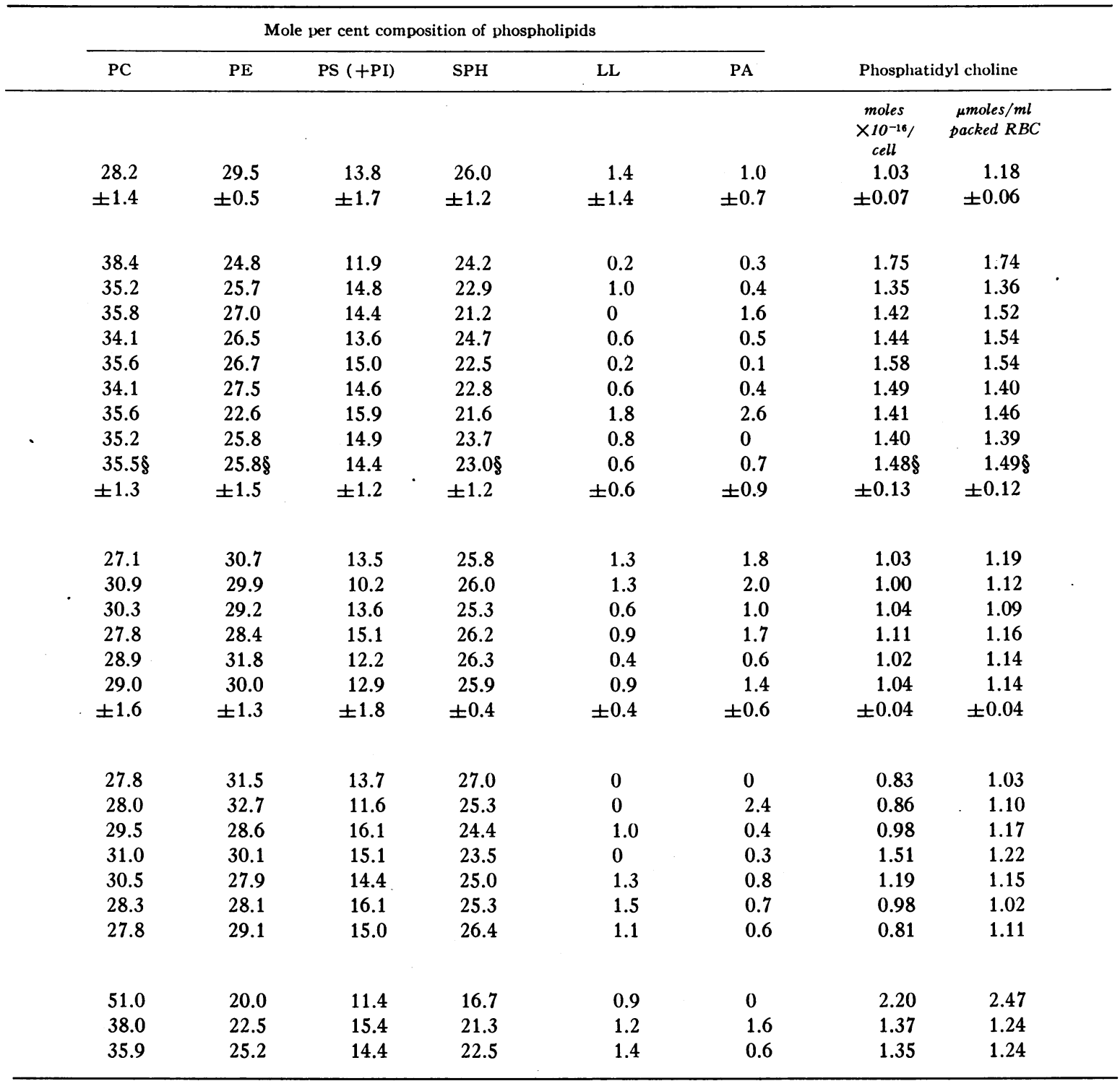

tory data and history and, in most cases, physical examination, eight patients were designated as definitely affected. Five individuals were classified as normal on the basis of laboratory investigations. Eight other members of the family had histories suggestive of a chronic hemolytic process, e.g., long-standing jaundice or cholecystectomy at an early age.

All eight subjects who were definitely affected had slight jaundice and splenomegaly. At least 


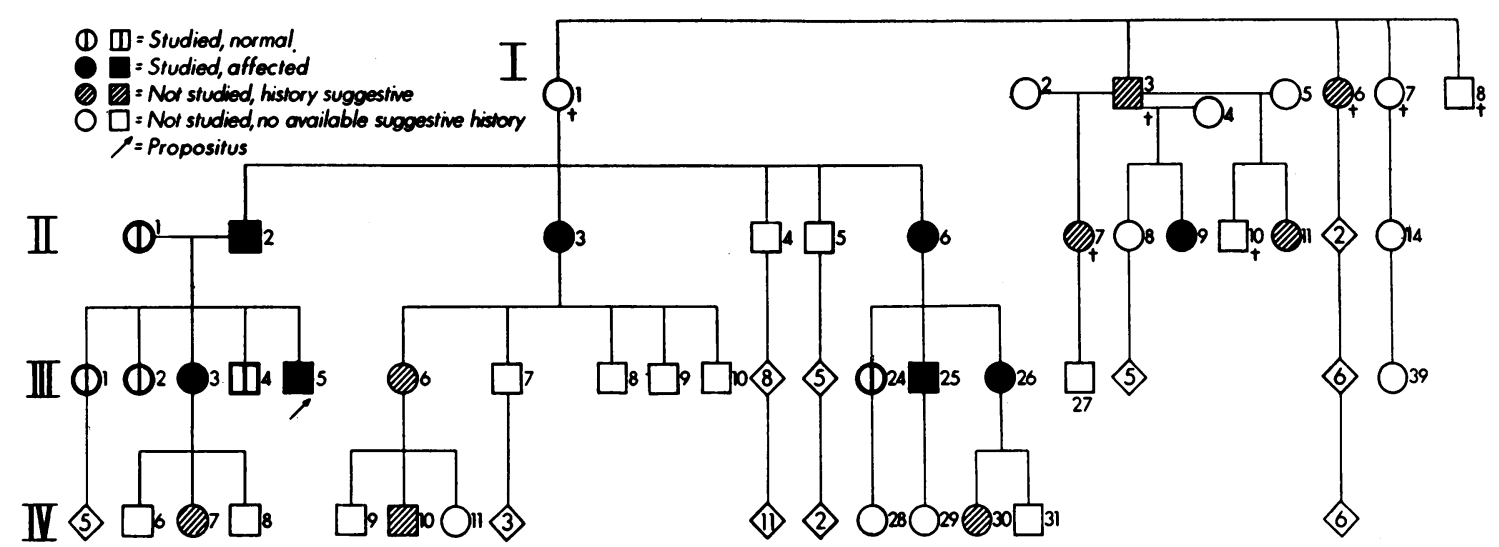

FIGURE 4 Pedigree of C. family with hereditary nonspherocytic hemolytic disorder. Numbers within diamonds represent number of offspring, sex not specified. $\dagger$, deceased. Circles, females. Squares, males.

two (III-25, III-26) were known to have been jaundiced at birth. Mild to moderate anemia was present in seven. All had a reticulocytosis of 7 to $15 \%$ and the morphology of the erythrocytes on stained smears of peripheral blood was similar to that of the propositus' smear. The unconjugated serum bilirubin concentration was elevated in all cases, but only one (II-3) had a slightly elevated conjugated bilirubin concentration. Liver function tests were normal, except that two patients had $2+$ to $3+$ cephalin flocculations. The unbound serum haptoglobin concentration was less than 50 $\mathrm{mg} / 100 \mathrm{ml}$ in the seven cases studied. The concentration of alkali-resistant hemoglobin (fetal) represented more than $4 \%$ of the total hemoglobin in three of seven subjects.

Lipid content of the erythrocytes and plasma.
The possibility was considered that this hemolytic disorder might have resulted from a defect in the cell membrane. Therefore, we determined the lipid composition of the erythrocytes.

A definite elevation was found in the lecithin content of the erythrocytes of the propositus (Table II). ${ }^{2}$ Studies of other members of the family also disclosed an increase in the lecithin content of the erythrocytes of each of the seven clinically affected subjects examined, and in none of five normal relatives (Table II). The relative composition of lecithin, ethanolamine phosphoglyc-

2 The authors are indebted to Drs. Aaron J. Marcus and Basil Bradlow for confirming the unusual phospholipid distribution in the erythrocytes of the propositus by independent quantitative thin-layer chromatographic analysis.

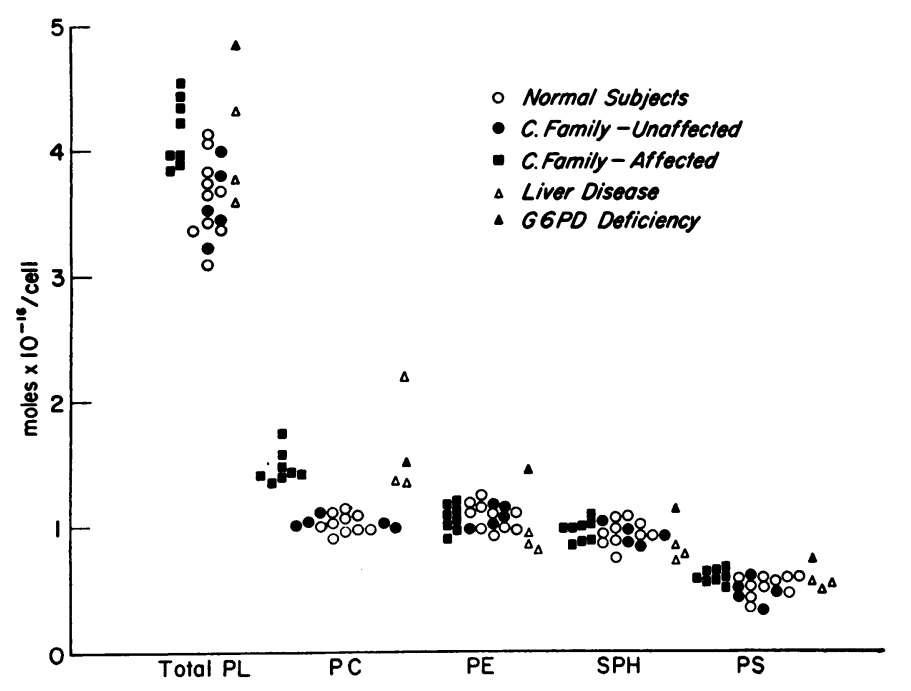

1382

E. R. Jaffé and E. L. Gottfried
FIGURE 5 Phospholipids of erythrocytes in normal subjects and in patients with hereditary nonspherocytic hemolytic disorder or liver disease. PL, phospholipids ; PC, phosphatidyl choline (lecithin); $\mathrm{PE}$, ethanolamine phosphoglycerides; SPH, sphingomyelin ; PS, phosphatidyl serine; G6PD, glucose-6-phosphate dehydrogenase. 
erides, and sphingomyelin showed highly significant deviations from the normal distribution of these phospholipids, but it was apparent that the altered phospholipid distribution was based entirely on an isolated increase in total lecithin content (Fig. 5). No significant difference was found in the absolute content of cholesterol, sphingomyelin, or ethanolamine phosphoglycerides. Total phosphatidyl serine content per cell was slightly elevated $(P<0.01)$, but the relative proportion of this phospholipid was normal $(P>0.4)$. The total plasmalogen content of the erythrocytes (mean value $5.69 \times 10^{-17} \mathrm{~mole} / \mathrm{cell}$ ) was within the normal range $\left(5.75 \times 10^{-17} \pm 0.73 \mathrm{sD}\right)$.

Dr. Lewis Gidez kindly analyzed the fatty acids of the total lipid extract and of an isolated lecithin fraction of the erythrocytes of the propositus by means of gas-liquid chromatography (32). The distribution of fatty acids was similar to that of normal control samples (Table III).

In order to rule out the possibility that the observed changes were nonspecific alterations in lipid composition related primarily to an increased proportion of young erythrocytes, we examined blood samples from adults with a variety of other congenital or long-standing hemolytic disorders (Table II). Reticulocyte levels as high as $29 \%$ and unconjugated serum bilirubin concentrations

TABLE III

Fatty Acid Composition of Phospholipids of Erythrocytes of the Propositus (III-5)*

\begin{tabular}{|c|c|c|c|c|}
\hline \multirow[b]{2}{*}{ Fatty acid } & \multicolumn{2}{|c|}{ Total phospholipid } & \multicolumn{2}{|c|}{ Lecithin } \\
\hline & Patient & Control & Patient & Controlf \\
\hline & \multicolumn{4}{|c|}{$\%$ of total fatty acids } \\
\hline $14: 0$ & 0.4 & 0.3 & 0.5 & 0.5 \\
\hline $16: 0$ & 20.3 & 22.1 & 42.7 & 49.1 \\
\hline $16: 1$ & trace & 0.7 & 0.2 & 1.1 \\
\hline $18: 0$ & 15.0 & 15.6 & 10.7 & 9.7 \\
\hline $18: 1$ & 17.0 & 13.4 & 22.3 & 18.4 \\
\hline $18: 2$ & 9.1 & 10.5 & 15.5 & 13.7 \\
\hline $20: 3$ & 1.8 & 1.2 & 1.3 & 0.7 \\
\hline $20: 4$ & 12.9 & 13.8 & $5.9 \S$ & 0.5 \\
\hline $22: ?$ & 3.4 & 2.2 & - & 2.4 \\
\hline $22: ?$ & trace & 1.9 & & \\
\hline $22: 4$ or $22: 6$ & 19.6 & 17.1 & & \\
\hline
\end{tabular}

* Gas chromatographic analysis of the phospholipid methyl esters was kindly performed by Dr. Lewis Gidez by the method outlined in reference 32. Control samples from a normal subject were prepared and analyzed at the same time as the samples from the patient's erythrocytes.

$¥$ Control sample also contained 15:0, 3.3\%.

8 A normal value; control value is too low. as high as $2.7 \mathrm{mg} / 100 \mathrm{ml}$ were observed in these patients. No comparable elevation of erythrocyte lecithin content was encountered, with one exception. One of two patients with glucose-6-phosphate dehydrogenase deficiency (A.R., age 26) had congenital nonspherocytic hemolytic anemia (hemoglobin $11.3 \mathrm{~g} / 100 \mathrm{ml}$, packed erythrocyte volume $39 \%$, total serum bilirubin $2.3 \mathrm{mg} / 100 \mathrm{ml}$ with $0.6 \mathrm{mg} / 100 \mathrm{ml}$ conjugated) with a high proportion of large young erythrocytes (reticulocytes $29 \%$ ). There was an increased content per cell not only of lecithin, but also of the other major phospholipids (Fig. 5). The relative proportions of phospholipids and the absolute phospholipid content based on packed cell volume, however, were normal.

Three patients with severe liver disease, hyperlipemia, and jaundice were found to have a marked increase in the lecithin content of the erythrocytes, in agreement with reports by Nye and Marinetti (33) and Ways (34). J.E. was a 28 yr old man with sclerosing cholangitis secondary to chronic ulcerative colitis. His hemoglobin was $9.9 \mathrm{~g} / 100$ $\mathrm{ml}$, packed erythrocyte volume $31 \%$, reticulocytes $1.7 \%$, and the total serum bilirubin was 20.0 $\mathrm{mg} / 100 \mathrm{ml}$ with $14.0 \mathrm{mg} / 100 \mathrm{ml}$ conjugated. M.S., a $47 \mathrm{yr}$ old woman with Laennec's cirrhosis, had a hemoglobin of $8.9 \mathrm{~g} / 100 \mathrm{ml}$, packed erythrocyte volume of $26.5 \%$, reticulocytes of $3.0 \%$, and a total serum bilirubin of $9.4 \mathrm{mg} / 100 \mathrm{ml}$ with 4.2 $\mathrm{mg} / 100 \mathrm{ml}$ conjugated. D.L. was a $65 \mathrm{yr}$ old woman with presumed fatty nutritional cirrhosis, probably secondary to chronic alcoholism. Her hemoglobin was $11.8 \mathrm{~g} / 100 \mathrm{ml}$, packed erythrocyte volume $33 \%$, reticulocytes $2.0 \%$, and the total serum bilirubin was $3.3 \mathrm{mg} / 100 \mathrm{ml}$ with $0.7 \mathrm{mg} /$ $100 \mathrm{ml}$ conjugated. In contrast to affected members of the family with the hemolytic disorder, these patients had extremely high plasma levels of total lipid, phospholipids, and cholesterol (Table IV).

Plasma lipids of six affected members of the C. family were unremarkable with respect to total lipid weight, total phospholipids, and cholesterol. A small but statistically significant difference was found, however, in the relative proportions of sphingomyelin (decreased) and lecithin (increased), as shown in Table IV. An abnormal lipoprotein, known to be present in obstructive hepatic disease with hyperlipemia and jaundice 
TABLE IV

Lipid Composition of Plasma

\begin{tabular}{|c|c|c|c|c|c|c|c|c|c|}
\hline \multirow[b]{2}{*}{ Subjects } & \multirow{2}{*}{$\begin{array}{l}\text { Total } \\
\text { lipid } \\
\text { weight }\end{array}$} & \multirow{2}{*}{$\begin{array}{c}\text { Total } \\
\text { cholesterol }\end{array}$} & \multirow{2}{*}{$\begin{array}{l}\text { Total } \\
\text { phospho- } \\
\text { lipid* }\end{array}$} & \multicolumn{6}{|c|}{ Mole $\%$ composition of phospholipidst } \\
\hline & & & & PC & SPH & LL & PS +PI & $\mathrm{PE}$ & PA \\
\hline $\begin{array}{l}\text { Normal subje } \\
\quad(n=10)\end{array}$ & $\begin{array}{l}\mathrm{mg} / 100 \mathrm{ml} \\
\mathrm{cts} 605\end{array}$ & $\begin{array}{c}m g / 100 m l \\
195\end{array}$ & $\begin{array}{c}m g / 100 m l \\
201\end{array}$ & 70.4 & 18.2 & 7.0 & 1.7 & 2.0 & 0.6 \\
\hline$\pm \mathrm{SD}$ & \pm 143 & \pm 69 & \pm 41 & \pm 2.4 & \pm 1.7 & \pm 1.3 & \pm 0.7 & \pm 0.9 & \pm 0.7 \\
\hline \multicolumn{10}{|c|}{ C. family, affected } \\
\hline III-3 & 637 & 147 & 170 & 69.8 & 14.6 & 9.6 & 2.8 & 2.8 & 0.4 \\
\hline III-25 & 625 & 194 & 232 & 76.2 & 14.5 & 5.4 & 1.9 & 2.0 & 0 \\
\hline III-26 & 717 & 196 & 260 & 73.6 & 14.6 & 4.5 & 3.0 & 3.7 & 0.6 \\
\hline II -2 & 492 & 142 & 157 & 75.1 & 12.7 & 6.7 & 2.1 & 3.4 & 0 \\
\hline II -3 & 810 & 216 & 183 & 69.9 & 17.4 & 5.1 & 2.3 & 4.6 & 0.7 \\
\hline II-6 & 702 & 196 & 228 & 75.1 & 13.8 & 7.9 & 1.0 & 2.2 & 0 \\
\hline Mean values & $664 \S$ & $182 \S$ & $205 \S$ & $73.3 \|$ & $14.6 \uparrow$ & $6.5 \S$ & $2.2 \S$ & $3.1 \S$ & $0.03 \S$ \\
\hline$\pm \mathrm{SD}$ & \pm 107 & \pm 30 & \pm 41 & \pm 2.8 & \pm 1.6 & \pm 2.7 & \pm 0.7 & \pm 1.0 & \pm 0.4 \\
\hline \multicolumn{10}{|c|}{ C. family, unaffected } \\
\hline III-1 & 276 & 109 & 108 & 67.4 & 16.6 & 7.4 & 4.0 & 3.8 & 0.8 \\
\hline III-2 & 600 & 147 & 188 & 66.3 & 17.1 & 6.9 & 4.5 & 3.6 & 1.6 \\
\hline III-24 & 814 & 309 & 300 & 62.0 & 26.8 & 5.0 & 2.0 & 3.6 & 0.6 \\
\hline II-1 & 547 & 128 & 153 & 74.4 & 14.6 & 5.5 & 2.3 & 3.0 & 0.2 \\
\hline Mean values & 559 & 173 & 250 & 67.5 & 18.8 & 6.2 & 3.2 & 3.5 & 0.8 \\
\hline$\pm \mathrm{SD}$ & \pm 221 & \pm 91 & \pm 82 & \pm 5.1 & \pm 5.5 & \pm 1.1 & \pm 1.2 & \pm 0.3 & \pm 0.6 \\
\hline \multicolumn{10}{|l|}{ Liver disease } \\
\hline J.E. & 2026 & 521 & 812 & 82.9 & 14.9 & 2.0 & 0 & 0.2 & 0 \\
\hline M.S. & 1168 & 427 & 411 & 69.0 & 15.4 & 5.8 & 3.8 & 5.0 & 1.0 \\
\hline D.L. & 1265 & 413 & 536 & 69.1 & 17.2 & 5.7 & 3.6 & 3.4 & 1.0 \\
\hline
\end{tabular}

* Calculated on the basis of average phosphorus content of $4 \%$.

$\ddagger$ Abbreviations as in Table II.

$\S$ No significant difference from normal.

$\| P<0.05$.

I $P<0.001$.

(35), was not detected in the plasma of the propositus. $^{3}$

\section{DISCUSSION}

The present investigation has provided evidence of an absolute and relative increase in the amounts of lecithin in the erythrocytes of eight affected members of a family with a hereditary nonspherocytic hemolytic disorder. Analyses of erythrocytes from other patients with hereditary or unexplained hemolytic disorders and comparable or greater levels of circulating reticulocytes have demonstrated no such alterations in the phospholipid composition of the cells. The total lipid content of

\footnotetext{
3 These studies were kindly performed by the late Dr. Sam Switzer.
}

young erythrocytes and reticulocytes has been reported to be increased, but the relative proportions of the phospholipids do not appear to be influenced by cell age (36). Bradlow et al. (37, 38 ), employing methods similar to those used here, have observed no consistent abnormalities in the distribution of phospholipids of erythrocytes in paroxysmal nocturnal hemoglobinuria or hereditary spherocytosis. Thus, the presence of a population of young erythrocytes per se does not appear to have accounted for the increase in the content of lecithin in the erythrocytes of the patients described here.

Farquhar and Ahrens (39) and Hill, Kuksis, and Beveridge (40) showed that modifications in the diet could influence the fatty acid composition 
of the lipids of human erythrocytes, but not the phospholipid distribution. Affected and unaffected members of the family with the hemolytic disorder lived in the same households and resided in both the United States and the Dominican Republic. Diet and other environmental influences, therefore, were considered to be unlikely factors in the development of the altered pattern of phospholipid distribution in the erythrocytes of these patients.

Special care was required in the extraction, storage, and analysis of the lipids because of the sensitivity of lipids to autoxidation, particularly in the presence of heme pigments. Dodge and Phillips (41) emphasized a common pitfall in the chromatographic analysis of erythrocyte lipids, viz., an apparent reduction in the content of ethanolamine or serine phosphoglycerides after unsuspected oxidative changes. Changes in these phosphoglycerides, which contain a relatively high proportion of polyunsaturated fatty acids, may lead to spurious "lysophosphatide" spots or generalized streaking on thin-layer chromatograms. In the present investigation, no loss of ethanolamine or serine phosphoglycerides was detected in blood samples from either normal subjects or patients. No evidence of unusual spots or abnormal lysophosphatides was encountered, nor was there any increase in absorbancy at 234 and $268 \mathrm{~m} \mu$, a sensitive measure of autoxidation (41), in lipid extracts from erythrocytes of affected patients. With the chromatographic system described here, a lysophosphatidyl ethanolamine reference standard had a mobility slightly faster than that of lecithin and could be distinguished readily from lecithin. Lecithin derived from erythrocytes of the patients with the hemolytic disorder produced a single spot on thin-layer chromatography with this and other solvent systems and yielded infrared spectra indistinguishable from those of authentic phosphatidyl choline. No ninhydrin-positive material could be detected in the region of the lecithin spot.

Extreme elevations in the lecithin content of erythrocytes and plasma from some patients with jaundice, liver disease, or hyperlipemia were reported by Nye and Marinetti (33). Ways (34) recently described a patient with liver disease and a mild hemolytic process in which a similar alteration in the composition of the phospholipids appeared to revert towards normal when the liver disease improved. In the present investigation. three patients with severe liver disease and markedly elevated plasma levels of total lipid, phospholipid, and cholesterol also were found to have increased amounts of lecithin in their erythrocytes. Both the patients with liver disease and those with the nonspherocytic hemolytic disorder were jaundiced. The relationship between the hyperbilirubinemia and the elevated content of lecithin in the erythrocytes of the patients with the hemolytic disorder and of the patients with severe liver disease cannot be explained at the present time. The hyperbilirubinemia in the patients with the hemolytic disorder was almost exclusively due to increased unconjugated bilirubin and these patients did not have clinical evidence of liver disease.

The clinical picture presented by affected members of the family described here was that of a fairly well compensated hemolytic disorder which did not appear to produce serious disability. The increase in autohemolysis, corrected nearly to normal by the addition of glucose, was characteristic of the hereditary nonspherocytic hemolytic disorders classified under type I (42). Dacie (42), Crosby (43), Motulsky et al. (44), DeGruchy et al. (45), Conrad et al. (46), and many others have described similar examples of this disorder. No evidence was obtained for an abnormal hemoglobin or a thalassemia syndrome. Slightly increased concentrations of alkali-resistant hemoglobin (fetal) were present in the erythrocytes of some affected individuals, but were also observed in other patients with long-standing hemolysis (45, 47). Enzymic deficiencies known to be associated with hereditary hemolytic disorders were excluded by direct assay, except for 2,3-diphosphoglycerate mutase and ATPase deficiencies. The former possibility appeared to be unlikely because of the elevated concentration of ATP consistent with the reticulocytosis, the increased utilization of glucose and production of lactate and pyruvate, the decreased osmotic fragility, the results of the autohemolysis tests, and the mild clinical course (4850). ATPase deficiency could not be excluded with certainty, but the degree of anemia in reported cases usually was greater, the reticulocytosis less marked, and the osmotic fragility would be expected to be increased (51). The diagnosis of a hereditary nonspherocytic hemolytic disorder, therefore, was made after eliminating other etiologies. The incidence and distribution of this dis- 
order in this family were compatible with an autosomal dominant mode of inheritance.

The decreased osmotic fragility and the minimal increase in fragility after incubation of blood from the patients described here were of interest and helped to rule out the diagnosis of hereditary spherocytosis. The findings were reminiscent of those noted with erythrocytes from patients with obstructive biliary tract disease and presumed to be secondary to elevated concentrations of erythrocyte cholesterol (52). The plasma and erythrocyte cholesterol concentrations of the patients with the hemolytic disorder, however, were normal. The role of the elevated lecithin content in the altered osmotic fragility pattern has not been determined. Association of the lipid changes with an increased ratio of surface area to volume might well account for the decreased osmotic fragility. The mere presence, however, of a high total lipid content in large young erythrocytes, as observed in the case of A. R. (Figs. 2 and 3 ), was not sufficient to produce such an increase in osmotic resistance. Differences in the osmotic fragility of the erythrocytes of various animal species have not been related directly to variations in lipid composition (36).

Most of the lipid of the mammalian erythrocyte probably is involved in the formation of the complex lipoprotein structure of the cell membrane (36). The phospholipid composition of erythrocytes is considered to be fairly constant within a given mammalian species (53). Although de novo synthesis of lipid probably does not occur in mature human erythrocytes (54), some exchange between the corresponding plasma and erythrocyte components has been demonstrated (3). The fractional turnover of lecithin in man in vivo and in vitro, for example, has been calculated to be $7 \%$ in $12 \mathrm{hr}$ (3). In abetalipoproteinemia, the young erythrocytes are normal in appearance and in phospholipid composition and the lipid alterations develop during the circulation of the mature erythrocytes (55). Thus, the phospholipid changes in acanthocytes have been considered to be secondary to the markedly abnormal plasma lipids and to have developed through the process of exchange (3). A similar mechanism may be responsible for the alteration in phospholipid content of the erythrocytes in certain patients with liver disease (33, $34)$. In the patients with the hereditary nonspherocytic hemolytic disorder, however, the plasma lipid distribution has shown only minor deviations from normal, which are of uncertain significance.

The change in the relative phospholipid distribution in the erythrocytes of the patients described here may have altered the membrane structure sufficiently to predispose the cells to premature destruction. On the other hand, the lipid changes may reflect a more fundamental derangement of cell membrane structure. Further investigations will be required to establish the nature of the basic defect in this disorder.

\section{ADDENDUM}

Since this paper was submitted for publication, one of the patients (III-26) was demonstrated to have an elevated ATPase activity (51) in her erythrocytes, and the 2,3diphosphoglycerate content (50) was normal. Thus, ATPase and 2,3-diphosphoglycerate mutase deficiency were considered not to be associated with this hemolytic disorder. The $5 \mathrm{yr}$ old daughter of this patient (IV-30, Fig. 4) was found to be affected by the same hemolytic disorder (erythrocyte lecithin phosphorus, 1.23 moles $\times$ $10^{-16}$ per cell, reticulocytes, $10 \%$, haptoglobin, $20 \mathrm{mg} / 100$ $\mathrm{ml}$, and jaundice). The $3 \mathrm{yr}$ old son of this patient (IV31, Fig. 4) had a normal blood count, no jaundice, and the lecithin phosphorus content of his erythrocytes was 0.95 mole $\times 10^{-16}$ per cell.

\section{ACKNOWLEDGMENTS}

The authors are deeply indebted to Dr. Juan Contin, without whose help none of these studies would have been possible, and to Dr. Thomas B. Bradley, Jr., who performed the studies on the survival of labeled erythrocytes in the propositus and who provided much valuable advice and assistance. Also, we gratefully acknowledge the expert assistance of Miss Gertrude Neumann, Mrs. Norma Robertson, and Mrs. Barbara Goldsmith.

The laboratory investigations were supported by U. S. Public Health Service grants HE-10041 and HE-08971. The clinical investigations were supported by U. S. Public Health Service grants AM-GM-09824 and FR-50. Dr. Jaffé and Dr. Gottfried are Career Scientists of the Health Research Council of the City of New York under awards I-169 and I-372, respectively.

\section{REFERENCES}

1. Simon, E. R., and P. Ways. 1964. Incubation hemolysis and red cell metabolism in acanthocytosis. J. Clin. Invest. 43: 1311.

2. Farquhar, J. W., and P. Ways. 1966. Abetalipoproteinemia. In The Metabolic Basis of Inherited Disease. J. B. Stanbury, J. B. Wyngaarden, and D. S. Fredrickson, editors. McGraw-Hill Book Company, New York. 2nd edition. 509. 
3. Weed, R. I., and C. F. Reed. 1966. Membrane alterations leading to red cell destruction. Am. J. Med. 41: 681 .

4. Kayden, H. J., and R. Silber. 1965. The role of vitamin $\mathrm{E}$ deficiency in the abnormal autohemolysis of acanthocytosis. Trans. Assoc. Am. Physicians. 78: 334 .

5. Dodge, J. T., G. Cohen, H. J. Kayden, and G. B. Phillips. 1967. Peroxidative hemolysis of red blood cells from patients with abetalipoproteinemia (acanthocytosis). J. Clin. Invest. 46: 357.

6. Arakawa, T., N. Katsushima, and T. Fujiwara. 1966. A hemolytic anemia with abnormality of erythrocyte lipids and dwarfism-probably a new syndrome. Tohoku J. Exptl. Med. 88: 35.

7. Folch, J., M. Lees, and G. H. Sloane Stanley. 1957. A simple method for the isolation and purification of total lipides from animal tissues. J. Biol. Chem. 226: 497.

8. Gottfried, E. L. 1967. Lipids of human leukocytes : relation to cell type. J. Lipid Res. 8: 321.

9. Leffler, H. H. 1960. Method for cholesterol and cholesterol esters in serum. In Lipids and the Steroid Hormones in Clinical Medicine; Proceedings of an Applied Seminar of the Association of Clinical Scientists. F. W. Sunderman and F. W. Sunderman, Jr., editors. J. B. Lippincott Co., Philadelphia. 18.

10. Gottfried, E. L., and M. M. Rapport. 1962. The biochemistry of plasmalogens. I. Isolation and characterzation of phosphatidal choline, a pure native plasmalogen. J. Biol. Chem. 237: 329.

11. Rapport, M. M., and W. T. Norton. 1962. Chemistry of the lipids. Ann. Rev. Biochem. 31: 103.

12. Skipski, V. P., R. F. Peterson, and M. Barclay. 1964. Quantitative analysis of phospholipids by thin-layer chromatography. Biochem. J. 90: 374.

13. Dacie, J. V., and S. M. Lewis. 1963. Practical Haematology. Grune \& Stratton, Inc., New York. 3rd edition. 140.

14. Selwyn, J. G., and J. V. Dacie. 1954. Autohemolysis and other changes resulting from the incubation in vitro of red cells from patients with congenital hemolytic anemia. Blood. 9: 414.

15. Rudolph, N., and R. T. Gross. 1966. Studies of invitro autohaemolysis in blood from newborn infants. Brit. J. Haematol. 12: 351.

16. Miller, G., P. L. Townes, and J. B. MacWhinney. 1965. A new congenital hemolytic anemia with deformed erythrocytes (?"stomatocytes") and remarkable susceptibility of erythrocytes to cold hemolysis in vitro. I. Clinical and hematologic studies. Pediatrics. $35: 906$.

17. Smithies, O. 1965. Characterization of genetic variants of blood proteins. Vox Sanguinis. 10: 359.

18. Marder, V. J., and C. L. Conley. 1959. Electrophoresis of hemoglobin on agar gels: frequency of hemoglobin D in a Negro population. Bull. Johns Hopkins Hosp. 105: 77.
19. Bucci, E., and C. Fronticelli. 1965. A new method for the preparation of $\alpha$ and $\beta$ subunits of human hemoglobin. J. Biol. Chem. 240: PC551. .

20. Dacie, J. V., A. J. Grimes, A. Meisler, L. Steingold, E. H. Hemsted, G. H. Beaven, and J. C. White. 1964. Hereditary Heinz-body anaemia. A report of studies on five patients with mild anaemia. Brit. J. Haematol. 10: 388 .

21. Rigas, D. A., and R. D. Koler. 1961. Decreased erythrocyte survival in hemoglobin $\mathrm{H}$ disease as a result of the abnormal properties of hemoglobin $\mathrm{H}$ : the benefit of splenectomy. Blood. 18: 1 .

22. Gross, R. T., R. Bracci, N. Rudolph, E. Schroeder, and J. A. Kochen. 1967. Hydrogen peroxide toxicity and detoxification in the erythrocytes of newborn infants. Blood. 29: 481.

23. Singer, K., A. I. Chernoff, and L. Singer. 1951. Studies on abnormal hemoglobins. I. Their demonstration in sickle cell anemia and other hematologic disorders by means of alkali denaturation. Blood. 6: 413 .

24. Marks, P. A. 1958. Red cell glucose-6-phosphate and 6-phosphogluconic dehydrogenases and nucleoside phosphorylase. Science. 127: 1338.

25. Gross, R. T., E. A. R. Schroeder, and S. A. Brounstein. 1963. Energy metabolism in the erythrocytes of premature infants compared to full term newborn infants and adults. Blood. 21: 755 .

26. Koutras, G. A., M. Hattori, A. S. Schneider, F. G. Ebaugh, Jr., and W. N. Valentine. 1964. Studies on chromated erythrocytes. Effect of sodium chromate on erythrocyte glutathione reductase. J. Clin. Invest. 43: 323.

27. Beutler, E. 1957. The glutathione instability of drugsensitive red cells. A new method for the in vitro detection of drug sensitivity. J. Lab. Clin. Med. 49: 84.

28. Beutler, E., O. Duron, and B. M. Kelly. 1963. Improved method for the determination of blood glutathione. J. Lab. Clin. Med. 61: 882.

29. Jaffé, E. R., and G. Neumann. 1968. Hereditary methemoglobinemia, toxic methemoglobinemia and the reduction of methemoglobin. Ann. N. Y. Acad. Sci. (In press).

30. McCurdy, P. R., and C. E. Rath. 1958. Splenectomy in hemolytic anemia. Results predicted by body scanning after injection of $\mathrm{Cr}^{\mathrm{N}}$-tagged red cells. New Engl. J. Med. 259: 459.

31. Snedecor, G. W. 1946. Statistical Methods Applied to Experiments in Agriculture and Biology. Iowa State College Press, Ames. 4th edition.

32. Gidez, L. I., P. S. Roheim, and H. A. Eder. 1965. Effect of diet on the cholesterol ester composition of liver and of plasma lipoproteins in the rat. J. Lipid Res. 6: 377 .

33. Nye, W. H. R., and G. V. Marinetti. 1965. Alterations in erythrocyte phospholipids produced by environmental change. J. Clin. Invest. 44: 1081.

34. Ways, P. 1967. An acquired reversible abnormality of erythrocyte lipids associated with liver disease and hemolytic anemia. J. Clin. Invest. 46: 1129. 
35. Switzer, S. 1967. Plasma lipoproteins in liver disease: I. Immunologically distinct low-density lipoproteins in patients with biliary obstruction. J. Clin. Invest. 46: 1855.

36. Van Deenen, L. L. M., and J. de Gier. 1964. Chemical composition and metabolism of lipids in red cells of various animal species. In The Red Blood Cell. A Comprehensive Treatise. C. Bishop and D. M. Surgenor, editors. Academic Press, Inc., New York. 243.

37. Bradlow, B. A., R. Rubenstein, and J. Lee. 1964. Quantitative thin-layer chromatography of phospholipids in normal human erythrocytes. S. African $J$. Med. Sci. 29: 41.

38. Bradlow, B. A., J. Lee, and R. Rubenstein. 1965. Erythrocyte phospholipids: quantitative thin-layer chromatography in paroxysmal nocturnal haemoglobinuria and hereditary spherocytosis. Brit. J. Haematol. $11: 315$.

39. Farquhar, J. W., and E. H. Ahrens, Jr. 1963. Effects of dietary fats on human erythrocyte fatty acid patterns. J. Clin. Invest. 42: 675.

40. Hill, J. G., A. Kuksis, and J. M. R. Beveridge. 1965. The effect of diet on the phospholipid composition of the red blood cells of man. J. Am. Oil Chemists' Soc. 42: 137.

41. Dodge, J. T., and G. B. Phillips. 1966. Autoxidation as a cause of altered lipid distribution in extracts from human red cells. J. Lipid Res. $7: 387$.

42. Dacie, J. V. 1960. The Haemolytic Anaemias. Congenital and Acquired. Part I-The Congenital Anaemias. Grune \& Stratton, Inc., New York. 2nd edition.

43. Crosby, W. H. 1950. Hereditary nonspherocytic hemolytic anemia. Blood. 5: 233.

44. Motulsky, A. G., W. H. Crosby, and H. Rappaport. 1954. Hereditary nonspherocytic hemolytic disease.
A study of a singular familial hemolytic syndrome. Blood. 9: 749.

45. DeGruchy, G. C., J. N. Santamaria, I. C. Parsons, and H. Crawford. 1960. Nonspherocytic congenital hemolytic anemia. Blood. 16: 1371.

46. Conrad, M. E., Jr., W. H. Crosby, and D. L. Howie. 1960. Hereditary nonspherocytic hemolytic disease. Am. J. Med. 29: 811.

47. Beaven, G. H., M. J. Ellis, and J. C. White. 1960. Studies on human foetal haemoglobin. II. Foetal haemoglobin levels in healthy children and adults and in certain haematological disorders. Brit. J. Haematol. 6: 201.

48. Löhr, Von G. W., and H. D. Waller. 1963. Zur Biochemie einiger angeborener hämolytischer Anämien. Folia Haematol. 8: 377.

49. Bowdler, A. J., and T. A. J. Prankerd. 1964. Studies in congenital non-spherocytic haemolytic anaemias with specific enzyme defects. Acta Haematol. 31: 65.

50. Schröter, W. 1965. Kongenitale nichtsphärocytäre hämolytische Anämie bei 2,3-Diphosphoglyceratmutase-Mangel der Erythrocyten im frühen Säuglingsalter. Klin. Wochschr. 43: 1147.

51. Harvald, B., K. H. Hanel, R. Squires, and J. TrapJensen. 1964. Adenosine-triphosphatase deficiency in patients with non-spherocytic haemolytic anaemia. Lancet. 2: 18.

52. Cooper, R. A., and J. H. Jandl. 1966. Mechanism of "target cell" formation in jaundice. Clin. Res. 14: 314.

53. De Gier, J., and L. L. M. van Deenen. 1961. Some lipid characteristics of red cell membranes of various animal species. Biochim. Biophys. Acta. 49: 286.

54. Marks, P. A., A. Gellhorn, and C. Kidson. 1960. Lipid synthesis in human leukocytes, platelets, and erythrocytes. J. Biol. Chem. 235 : 2579.

55. Ways, P., and D. Dong. 1965. Etiology of the RBC phospholipid abnormalities in a-beta lipoproteinemia. Clin. Res. 13: 283. 